\title{
Role of Minerals Supplementation on Growth and Survival of Litopenaeus vannamei in Low Salinity Water
}

\author{
K. Veeranjaneyulu ${ }^{1^{*}}$ and G. Krishnaveni ${ }^{2}$ \\ ${ }^{I}$ National Fisheries Development Board, Hyderabad, India \\ ${ }^{2}$ Krishi Vigyan Kendra, Kampasagar, Nalgonda, India \\ *Corresponding author
}

\begin{tabular}{|l|}
\hline Ke y w o r d s \\
$\begin{array}{l}\text { Litopenaeus } \\
\text { vannamei, Shrimp, } \\
\text { Dietary mineral, } \\
\text { growth }\end{array}$ \\
\hline Article Info \\
\hline $\begin{array}{l}\text { Accepted: } \\
20 \text { November } 2018 \\
\text { Available Online: } \\
10 \text { December } 2018\end{array}$ \\
\hline
\end{tabular}

\section{Introduction}

The culture of shrimp and other fish and crustaceans using low salinity water is a trend that continues to grow throughout the world. In 2011, aquaculture accounted for $52.5 \%$ of the world's fish food supply (FAO 2011). Most fish, crustacean and mollusc aquaculture production $(61 \%)$ occurs in inland waters. In
The present study "Effect of Aqueous and dietary minerals supplementation on growth and survival of Litopenaeus vannamei in low salinity water" was conducted in the Krishi Vigyan Kendra, Kampasagar, Nalgonda of Professor Jayashankar Telangana state Agriculture University. L. vannamei culture in inland low salinity water in currently being practiced various parts of the country. These environments are often deficient in key ions essential for normal physiological function of shrimp, which resulted in reduced growth and mortalities. In the present study it has been evaluated to identify the efficient source mineral supplementation for L. vannamei in low salinity waters. Aqueous and dietary mineral supplementations were tested for the efficiency on survival and growth of $L$. vannamei in low salinity water. Experiments were conducted at 3 ppt salinity bore well water for throughout the period of 7 weeks. Dietary mineral supplementation source was proved to be the best option for mineral supply for L.vannamei in low salinity water culture. In the dietary mineral supplementation treatments highest growth performance of $3.92 \mathrm{~g}$ and survival $(80 \%)$ were recorded for potassium $\left(\mathrm{K}^{+} 10 \mathrm{~g}\right.$ and $\mathrm{Na}^{+} 20 \mathrm{~g}$ per $\mathrm{kg}$ diet $)$ supplementation. FCR lowest is recorded in potassium dietary mineral supplementation treatment. Highest growth performance in vannamei was observed for magnesium $\left(\mathrm{Mg}^{2+}\right.$ $80 \mathrm{mg}^{-1}$ ) addition to that water among all aqueous mineral supplementation treatment. The highest survival of $70 \%$ was recorded for potassium $\left(30 \mathrm{mg}^{-1}\right)$ treatment among all aqueous mineral supplementation treatment. All the aqueous and dietary mineral supplementation treatments indicated highest growth and survival than control treatment. 
total shrimp and prawn production worldwide (FAO 2011). All indications are that the production of $L$. vannamei will continue to expand, particularly in countries such as China, Vietnam and Thailand. The Pacific white shrimp is a euryhaline species that can tolerate a wide range of salinities $0.5-45 \mathrm{~g}$ $\mathrm{L}^{-1}$ (Menz and Blake 1980; Bray et al., 1994). There are even some indications that it is capable of growing in waters of less than $0.5 \mathrm{~g}$ $\mathrm{L}^{-1}$ (Araneda et al., 2008; Cuvin-Aralar et al., 2009). The remarkable ability of L. vannamei to grow in less than ideal environments has made it the species of choice for culturing in low salinity water (Dall et al., 1990, Rothlisberg, 1998 and Alday-Sanz, 2010).

To overcome these disease problems, one proposed solution to whiteleg shrimp production problems is the use of water with salinities lower than sea water. Several researchers (Van Wyk et al., 1999: McGraw et al., 2002: Saoud et al., 2003: Sowers and Tomasso 2006a) have studied the growth of $L$. vannamei in different salinities. In the same way an attempt has been made in zero salinity to study the growth of L. Vannamei.

During the last few years, white spot disease (WSD) has spread worldwide and caused large scale mortalities and severe damage to shrimp culture, particularly in Asia leading to massive economic losses. Due to continuous outbreak of WSSV in of P.monodon culture leads to shattering of shrimp culture in India. So the farmers are seriously looking for alternative species for culture. At right time the Coastal Aquaculture Authority of India (CAA) introduced a new species (Litopenaeus vannamei) in India.

At the same time CAA is very keen in the bio security and approval for culture of $L$. vannamei. The shrimp has been introduced and farmed in Asia since the mid 1990s, with production in Mainland China being particularly significant. However, beginning in 1996, L. vannamei was introduced into Asia on a commercial scale. Total production of $L$. vannamei in Asia was approximately 3, $16,000 \mathrm{mt}$ in 2002.

It is now evident that L. vannamei is farmed and established in several countries in East, Southeast and South Asia and is playing a major significant role in shrimp aquaculture production. There is very limited research works were done on the culture and growth performance of $L$. vannamei with different stocking densities in brackish water ponds in India. Owing to its ability to grow and survive in low salinity environments the Pacific white shrimp, (Litopenaeus vannamei, Boone) has become the candidate of choice for low salinity culture.

Inland production of $L$. vannamei in lowsalinity water is a growing industry in several regions of the world. Depending on their source, inland waters available for shrimp culture are usually of different salinities and possess different ion compositions (Boyd and Thunjai, 2003). Inland shrimp culture has been practiced for several years with tiger shrimp in Thailand (Flaherty and Vandergeest, 1998), and white shrimp has been cultivated inland in several regions of the United States (Davis et al., 2002). Factors such as absence of white spot syndrome virus (WSSV) in water sources (Sanchez-Barajas et al., 2009), adequate environmental temperatures year around, low equipment corrosion and proximity to large markets have permitted the establishment of several farms totalling 350 ha, which produced in 2007 over 1500 metric tons (Industria Acuícola, 2008) have permitted for the expantion of culture in inland low salinity waters.

A dietary source of 23 minerals has been demonstrated as essential in 1 or more animal species. These elements are divided into two 
groups: the 7 macrominerals (calcium, chlorine, magnesium, phosphorus, potassium, sodium, and sulfur) and 16 trace minerals (aluminium, arsenic, cobalt, chromium, copper, fluorine, iodine, iron, manganese, molybdenum, nickel, selenium, silicon, tin, vanadium, zinc). Thirteen minerals are required in the diet of most terrestrial animals and may be essential for aquatic animals. Among these minerals, eight are cations: calcium $\left(\mathrm{Ca}^{2+}\right), \quad \operatorname{copper}\left(\mathrm{Cu}^{2+}\right), \quad \operatorname{iron}\left(\mathrm{Fe}^{2+}\right)$, magnesium $\left(\mathrm{Mg}^{2+}\right)$ manganese $\left(\mathrm{Mn}^{2+}\right)$, potassium $\left(\mathrm{K}^{+}\right)$, sodium $\left(\mathrm{Na}^{+}\right)$, and $\operatorname{zinc}\left(\mathrm{Zn}^{2+}\right)$; and five anions or are usually found in anionic groupings: $\quad$ chloride $\left(\mathrm{Cl}^{-}\right), \quad$ iodine $\left(\mathrm{I}^{-}\right)$, molibdinum $\left(\mathrm{Mo}^{2-}\right)$, phosphate $\left(\mathrm{PO}_{4}{ }^{3-}\right)$ and selenite $\left(\mathrm{SeO}_{3}{ }^{2-}\right)$ (Scott et al., 1982).

With the exception of osmoregulation, the maintenance of osmotic balance between body fluids and the water in which the animal lives, the biochemical functions of minerals in aquatic species appear to be similar to those in terrestrial animals (Lovell, 1989). Fresh water species lose ions to the hypotonic environment and therefore suffer from hydration, where as the reverse is true for marine species. Unlike terrestrial animal, which are primarily limited to a dietary source of minerals, aquatic animals may be able to utilize, to some extent, minerals dissolved in the water to meet physiological requirements. Calcium, Copper, Iron, Magnesium, Potassium, Sodium, Selenium, and Zinc are generally derived from the water to satisfy part of the physiological requirements of fish (National Research Council, 1993).

Since aquatic animals can obtain minerals from both ambient water and feed, dietary supplements of selected minerals could facilitate better survival and growth of shrimp held in low salinity conditions. If one looks at the mineral profile of most low salinity well waters as compared to the profiles of low salinity water of oceanic origin you find that the levels of potassium and magnesium are much lower in the low salinity well water source. A marine species reared in seawater do not require dietary sources of magnesium and potassium, whereas freshwater species reared in freshwater do. Consequently, these minerals may be low in marine shrimp feeds that are fed to marine shrimp reared in low salinity water.

Recommendations and research into the influence of minerals on growth and survival in low salinity water is warranted. The ionic composition of saline water appears to be more important than salinity with regards to its effect on shrimp survival and growth. This is probably due to the fact that most of these waters contain adequate levels of sodium and chloride to meet the shrimp's physiological requirement. However, other ions are not at sufficient levels in the water or possibly the diet to meet physiological requirements. Quite often inland shrimp farmers complain of a slow die-off of shrimp. They report that shrimp are easily stressed by handling, temperature and low dissolved oxygen levels of the water. The farmers often observe lethargic shrimp along the sides of nursery tanks and ponds, or stressed shrimp even after gentle handling. Stress is often characterized by a whitening of the tail, cramping and possibly death. A probable reason for this response would be ionic imbalances and nutrient reserves caused by this unique environment.

The objectives of present study are:

The effect of identified minerals like ( $\mathrm{Na}, \mathrm{K}$ and $\mathrm{Mg}$ ) supplements through aqueous and dietary source on growth and survival of $L$. vannamei.

Among the both aqueous and dietary minerals supplementation which gives better growth and survival of L. vannamei in low salinity water. 


\section{Materials and Methods}

\section{Site of the experiment}

The experiment was conducted in Krishi Vigyan Kendra, Kampasagar, Nalgonda of Professor Jayashankar Telangana state Agriculture University for a period of 7 weeks.

\section{Experimental animals and their acclimatization}

Litopenaeus vannamei (1000 numbers) were obtained from CP Hatchery, Nellore, who has been authorized by Coastal Aquaculture Authority (CAA), Chennai to produce seed. Post larvae (PL10) transported by road in plastic bags containing $15 \mathrm{ppt}$ saline water. PL transferred to the same salinity water in the wet lab. Acclimatization was carried out over 8 days. During this time salinity was lowered from $15 \mathrm{ppt}$ to $3 \mathrm{ppt}$ bore well water at an average rate of $4 \mathrm{ppt}$ day $^{-1}$ (M. Araneda et al., 2008). During this period the seed were fed with control diet. Shrimp seed were packed in double plastic bags filled with oxygen and water in the ratio of $3: 1$ in each bag and the density of shrimp was 300/bag. The number of shrimp seed to be packed in oxygen inflated polythene bags was calculated as per the following formula (Jameson et al., 1995).

$\mathrm{N}=(\mathrm{DO}-2) \mathrm{X} \mathrm{V/CH}$

Where:

DO: Dissolved oxygen content of water $(\mathrm{mg} / \mathrm{l})$

$\mathrm{V}$ : Volume of water used for transport (Lt)

C: Rate of oxygen consumption of shrimp ( $\mathrm{ml} / \mathrm{kg}$ of shrimp)

H: Duration of transport (Hours)

\section{Experimental design}

The aquarium tanks used for experiments were of size $60 \times 30 \times 30 \mathrm{~cm}$ (Plate 1). Twenty one aquariums were stalked on iron racks. Aquariums were located in a secured place where there is no direct sunlight and covered all the sides with black paper to avoid algal growth in the tank. Water in the aquariums was aerated by using air stones connected to the air compressor. Filters are used for filtering the aquarium water. The underground water was taken into a tank and allowed to aerate for 48 hours and was used for filling the aquaria. Salinity was checked before taken the water into aquarium. The water is allowed to filter for 24 hours before introducing the shrimps into the aquaria.

Ten numbers of Shrimps with initial average weights of $0.15-0.18 \mathrm{gm}$ were introduced in to each aquarium and triplicates were maintained for each treatment (Dietary supplementation of (plate 2) Na-10g, Na-20g, $\mathrm{K}-5 \mathrm{~g}, \mathrm{~K}-10 \mathrm{~g}, \mathrm{Mg}-150 \mathrm{mg}, \mathrm{Mg}-300 \mathrm{mg}$ and Aqueous supplementation of K-20mg, K30mg, Mg-40mg, Mg-80mg) includes control. Regular water exchange of $25 \%$ was done every day. Left over feed, excreta and other debris was siphoned off from the bottom of the tank without disturbing the shrimps.

\section{Experimental feed preparation and Feeding}

In the experiment, formulated feed with the crude protein $(35 \%)$ were used for feeding. Fishmeal, soybean meal, groundnut oil cake, maize and deoiled ricebran were the ingredients used for control feed. Experimental diets were prepared with same ingredients as used in control diet. In addition to that experimental diet contained following mineral $5 \mathrm{~g}$ potassium $\left(\mathrm{K}^{+}\right)$. Each diet was prepared separately by adding $10 \mathrm{~g}$ potassium, $10 \mathrm{~g}$ sodium, $20 \mathrm{~g}$ sodium, $150 \mathrm{mg}$ magnesium, $300 \mathrm{mg}$ magnesium. $1 \%$ of vitamin mixture added to experimental diets. All the ingredients that are Soybean meal, deoiled rice bran, maize, ground nut oil cake, vitamins used in feeds were obtained from local 
markets. Ingredients used in the feed and all the experimental diets were estimated for proximate composition (AOAC, 1995).

Each ingredient was procured in required quantity and ground into powder and sieved. All the ingredients were then mixed in required proportion and water was added at the rate of $30 \mathrm{ml}$ per every $100 \mathrm{~g}$ of feed and dough was prepared. Maida (1\%) was used as a binding agent in the feed. The dough was cooked for 20 minutes in pressure cooker and then cooled. $1 \%$ Vitamin mixture was added. The homogenous dough was pressed through a hand pelletizer (La Monferrina s.r.l, Italy) with a sieve of $1 \mathrm{~mm}$ diameter. The feed was dried in shade and then in hot air oven at 80$90^{\circ} \mathrm{C}$ to reduce the moisture content to $10 \%$ and stored properly in dry and air tight bottles and kept in dark cool place.

\section{Proximate composition}

Proximate analysis of the feed was estimated by the method of AOAC, 1995.

\section{Results and Discussion}

\section{Growth}

Growth of L. vannamei fed with dietary minerals supplementation

Weight of shrimp in grams and weight increment data observed weekly for different treatments. Observations on the growth during the first week ( $7^{\text {th }}$ day) revealed that weight increment varied between $0.41 \pm 0.04$ and $0.50 \pm 0.10 \mathrm{gms}$ for treatment control and $\mathrm{Na}$ $10 \mathrm{~g}$ respectively. Highest and lowest average weight values were observed in the treatments $\mathrm{K}-10 \mathrm{~g}(0.68 \pm 0.02)$ and control $(0.57 \pm 0.12)$. On the $14^{\text {th }}$ day highest increment of $0.54 \pm 0.12 \mathrm{gms}$ and lowest increment of $0.41 \pm 0.11 \mathrm{gms}$ were recorded for the $\mathrm{k}-10 \mathrm{~g}$ and control respectively. Highest average weight values $(1.14 \pm 0.07)$ and lowest average weight values $(0.98 \pm 0.04)$ were recorded for $\mathrm{Na}-20 \mathrm{~g}$ and control respectively during the second sample $\left(14^{\text {th }}\right.$ day). Similar trend continued during the $21^{\text {st }}$ day also. The highest and lowest weight growth of increment observed were $0.51 \pm 0.11$ and $0.40 \pm 0.10 \mathrm{gms}$ for $\mathrm{Na}-20 \mathrm{~g}$ and $\mathrm{K}-10 \mathrm{~g}$ respectively, while the highest and lowest average weight values observed were $(1.65 \pm 0.09$ and $1.43 \pm 0.11)$ for $\mathrm{Na}-20 \mathrm{~g}$ and control respectively. Treatments $\mathrm{Na}-10 \mathrm{~g}$ and $\mathrm{K}-10 \mathrm{~g}$ stood in second and third positions with growth in weight of $1.63 \pm 0.12$ and $1.62 \pm 0.05$ respectively. During the $28^{\text {th }}$ day, the highest and lowest weight increments observed were $0.57 \pm 0.07$ and $0.39 \pm 0.05 \mathrm{gms}$ for $\mathrm{K}-10 \mathrm{~g}$ and control respectively. The highest and lowest average weight values observed were $(2.19 \pm 0.04$ and $1.82 \pm 0.07)$ for $\mathrm{K}-10 \mathrm{~g}$ and control respectively. Treatments $\mathrm{Na}-20 \mathrm{~g}$ and $\mathrm{Mg}-300 \mathrm{mg}$ stood in second and third positions with weight growth of $2.18 \pm 0.07$ and $2.16 \pm 0.07 \mathrm{gms}$ respectively. Similar trend continued during the $35^{\text {th }}$ day of the experiment also. Highest and lowest weight growth increments observed were $0.54 \pm 0.04$ and $0.46 \pm 0.07 \mathrm{gms}$ for $\mathrm{K}-10 \mathrm{~g}$ and Mg-150mg respectively. The highest and lowest average weight values observed were $(2.73 \pm 0.12$ and $2.30 \pm 0.05)$ for $\mathrm{K}-10 \mathrm{~g}$ and control respectively. $\mathrm{Mg}-300 \mathrm{mg}$ and $\mathrm{Na}-10 \mathrm{~g}$ stood in second and third positions with growth weight gain of $2.65 \pm 0.05$ and $2.63 \pm 0.14 \mathrm{gms}$ respectively. On the $42^{\text {nd }}$ day highest increment of $0.59 \pm 0.09 \mathrm{gms}$ and lowest increment of $0.36 \pm 0.14 \mathrm{gms}$ were recorded for the $\mathrm{K}-5 \mathrm{~g}$ and control respectively. Highest average weight values $3.21 \pm 0.10$ and lowest average weight values $2.66 \pm 0.03$ were recorded for $\mathrm{K}-5 \mathrm{~g}$ and control respectively. On the $49^{\text {th }}$ day highest increment of $0.72 \pm 0.10 \mathrm{gms}$ and lowest increment of $0.42 \pm 0.11 \mathrm{gms}$ were recorded for the $\mathrm{K}-10 \mathrm{~g}$ and control respectively. Highest average weight values $3.92 \pm 0.06$ and lowest average weight values $3.08 \pm 0.07$ were recorded for K- 
$10 \mathrm{~g}$ and control respectively. Also highest average weight values of $3.92 \pm 0.06$ from K$10 \mathrm{~g}$ and lowest average weight values of $3.08 \pm 0.07$ from control were observed at the end of the experiment. An overall study indicated that the $\mathrm{K}-5 \mathrm{~g}$ recorded total weight increment of $3.87 \pm 0.07 \mathrm{~g}$ in the 49 days experimental period. This was followed by the $\mathrm{Na}-20 \mathrm{~g}$ (3.71 \pm 0.08$)$, Na-10g $(3.70 \pm 0.04 \mathrm{gm})$ and $\mathrm{Mg}-300 \mathrm{mg}(3.69 \pm 0.08 \mathrm{gm})$, they stood in second, third and fourth positions respectively.

The growth data was subjected to analysis of variance (ANOVA) at 5\% level of significance and the observations were presented. The statistical analysis has shown that $\mathrm{F}$ - value is found to be significant among treatments. Since F- value is found to be significant, the pair wise comparison of any two Treatments could be done by computing RBD two way classification. The Treatment $\mathrm{K}-10 \mathrm{~g}$ is found to be significantly superior when compare to other Treatments. Treatment $\mathrm{K}-10 \mathrm{~g}$ has shown significantly different from all other Treatments. The second and third positions were occupied by $\mathrm{Na}-20 \mathrm{~g}$ and $\mathrm{K}-5 \mathrm{~g}$ respectively. There was a significant difference between the culture periods also.

\section{Growth of L. vannamei supplied with aqueous minerals}

Weight of shrimp in grams and weight increment data observed weekly for different treatments were studied. Observations on the growth during the first week ( $7^{\text {th }}$ day) revealed that weight increment varied between $0.41 \pm 0.04$ and $0.48 \pm 0.07 \mathrm{gms}$ for treatment control and K-20mg respectively. Highest and lowest average weight values were observed in the treatments $\mathrm{Mg}-80 \mathrm{mg}(0.64 \pm 0.05)$ and control $(0.57 \pm 0.12)$. On the $14^{\text {th }}$ day highest increment of $0.49 \pm 0.10 \mathrm{gms}$ and lowest increment of $0.41 \pm 0.11 \mathrm{gms}$ were recorded for the $\mathrm{Mg}-80 \mathrm{mg}$ and control respectively. Highest average weight values $(1.13 \pm 0.14)$ and lowest average weight values $(0.98 \pm 0.04)$ were recorded for $\mathrm{Mg}-80 \mathrm{mg}$ and control respectively during the second sample $\left(14^{\text {th }}\right.$ day). Similar trend continued during the $21^{\text {st }}$ day also. The highest and lowest weight growth of increment observed were $0.47 \pm 0.09$ and $0.37 \pm 0.14 \mathrm{gms}$ for $\mathrm{Mg}-80 \mathrm{mg}$ and $\mathrm{K}-30 \mathrm{mg}$ respectively, while the highest and lowest average weight values observed were $(1.60 \pm 0.02$ and $1.43 \pm 0.04)$ for $\mathrm{Mg}-80 \mathrm{mg}$ and $\mathrm{K}-30 \mathrm{mg}$ respectively. Treatments K-20mg and Mg-40mg stood in second and third positions with growth in weight of $1.56 \pm 0.04$ and $1.45 \pm 0.02$ respectively. During the $28^{\text {th }}$ day, the highest and lowest weight increments observed were $0.45 \pm 0.12$ and $0.39 \pm 0.02 \mathrm{gms}$ for $\mathrm{Mg}-80 \mathrm{mg}$ and $\mathrm{K}-30 \mathrm{mg}$ respectively. The highest and lowest average weight values observed were $(2.09 \pm 0.07$ and $1.82 \pm 0.01)$ for $\mathrm{K}-20 \mathrm{mg}$ and K-30mg respectively. Treatments Mg-80mg and Mg-40mg stood in second and third positions with weight growth of $2.05 \pm 0.11$ and $1.86 \pm 0.07 \mathrm{gms}$ respectively. Similar trend continued during the $35^{\text {th }}$ day of the experiment also. Highest and lowest weight growth increments observed were $0.53 \pm 0.07$ and $0.44 \pm 0.05 \mathrm{gms}$ for K-30mg and $\mathrm{Mg}-40 \mathrm{mg}$ respectively. The highest and lowest average weight values observed were (2.55 \pm 0.11 and $2.30 \pm 0.05)$ for $\mathrm{K}-20 \mathrm{mg}$ and control respectively. $\mathrm{Mg}-80 \mathrm{mg}$ and $\mathrm{K}-30 \mathrm{mg}$ stood in second and third positions with growth weight gain of $2.51 \pm 0.12$ and $2.35 \pm 0.05 \mathrm{gms}$ respectively. On the $42^{\text {nd }}$ day highest increment of $0.60 \pm 0.05 \mathrm{gms}$ and lowest increment of $0.36 \pm 0.14 \mathrm{gms}$ were recorded for the $\mathrm{Mg}-80 \mathrm{mg}$ and control respectively. Highest average weight values $3.11 \pm 0.04$ and lowest average weight values $2.66 \pm 0.03$ were recorded for $\mathrm{Mg}-80 \mathrm{mg}$ and control respectively. On the $49^{\text {th }}$ day highest increment of $0.56 \pm 0.12 \mathrm{gms}$ and lowest increment of $0.42 \pm 0.11 \mathrm{gms}$ were recorded for the K-20mg and control respectively. Highest average weight values $3.65 \pm 0.07$ and lowest average weight values $3.08 \pm 0.07$ were 
recorded for $\mathrm{Mg}$-80mg and control respectively. Also highest average weight values of $3.65 \pm 0.07$ from $\mathrm{Mg}-80 \mathrm{mg}$ and lowest average weight values of $3.08 \pm 0.07$ from control were observed at the end of the experiment. An overall study indicated that the K-20mg recorded total weight increment of $3.64 \pm 0.05 \mathrm{~g}$ in the 49 days experimental period. This was followed by the $\mathrm{Mg}-40 \mathrm{mg}$ $(3.30 \pm 0.05), \quad K-30 \mathrm{mg} \quad(3.28 \pm 0.07 \mathrm{gm})$ they stood in second and third positions respectively.

The growth data was subjected to analysis of variance (ANOVA) at 5\% level of significance and the observations were studied. The statistical analysis has shown that F- value is found to be significant among treatments. Since F- value is found to be significant, the pair wise comparison of any two Treatments could be done by computing RBD two way classification. The Treatment $\mathrm{Mg}-80 \mathrm{mg}$ is found to be significantly superior when compare to other Treatments. Treatment Mg-80mg has shown significantly different from all other Treatments. The second and third positions were occupied by K-20mg and Mg-40mg respectively. There was a significant difference between the culture periods also.

\section{Survival rate}

\section{Survival of $L$. vannamei fed with dietary minerals supplementation}

Survival percentages of L. vannamei shrimp in various experimental treatments are presented. The survival percentage throughout the period of experiment was lowest for the control, $\mathrm{Mg}$ 150mg, Mg-300mg, k-5g, Na-10g, Na-20g, K$10 \mathrm{~g}$. By the final sampling $\left(49^{\text {th }}\right.$ day) the survival percentage was (highest) 80.0 - and (lowest) 50.0.

The survival data was subjected to analysis of variance (ANOVA) presented. Statistical analysis has shown that $\mathrm{F}$ - value is found to be significant among treatments. Since F- value is found to be significant, the pair- wise comparison of any two treatments could be done by computing RBD two way classifications. The treatment $\mathrm{K}-10 \mathrm{~g}$ had shown highest survival rate when compared to the other treatments. The subsequent positions were occupied by Treatments Na-20g, K-5g, Mg-300mg, Na-10g, Mg-150mg followed by control. Treatment K-10g has shown significant difference from all other treatments. There was significant difference in between experimental period also.

\section{Survival of L. vannamei supplied with aqueous minerals}

Survival percentages of $L$. vannamei shrimp in various experimental treatments were presented. The survival percentage throughout the period of experiment was lowest for the control, K-20mg, Mg-40mg, Mg-80mg and K$30 \mathrm{mg}$. By the final sampling $\left(49^{\text {th }}\right.$ day) the survival percentage was (highest) 70.0 - and (lowest) 50.0.

The survival data was subjected to analysis of variance (ANOVA) presented. Statistical analysis has shown that F- value is found to be significant among treatments. Since F- value is found to be significant, the pair- wise comparison of any two treatments could be done by computing RBD two way classification. The treatment K-30mg had shown highest survival rate when compared to the other treatments. The subsequent positions were occupied by Treatments K-30mg, Mg80mg, Mg-40mg, K-20mg followed by control. Treatment K-30mg has shown significant difference from all other treatments. There was significant difference in between experimental period also.

\section{Specific growth rates}


Specific growth Rates of $L$. vannamei fed with dietary minerals

\section{Supplementation}

Specific growth rates for L. vannamei treated with different diets were calculated and studied. The specific growth rates by end of the experimental period (49 days) were calculated for all treatments.

Control group has the lowest Specific Growth Rate of $6.03 \%$. The highest value was in $\mathrm{Mg}$ $150 \mathrm{mg}$ with $6.50 \%$. The treatments that stood second and third positions were $\mathrm{Na}-10 \mathrm{~g}$ (6.41\%) and $\mathrm{Mg}-300 \mathrm{mg}$ (6.40\%). These were followed by $\mathrm{K}-10 \mathrm{~g}(6.28 \%), \mathrm{K}-5 \mathrm{~g}(6.26 \%)$ and $\mathrm{Na}-20 \mathrm{~g}(6.17 \%)$ respectively.

Specific growth rates of $L$. vannamei supplied with aqueous minerals supplementation

Specific growth rates for $L$. vannamei (whiteleg shrimp) treated with different diets were calculated and studied. The specific growth rates by end of the experimental period (49 days) were calculated for all treatments.

Control group has the lowest Specific Growth Rate of $6.03 \%$. The highest value was in K$20 \mathrm{mg}$ with $6.50 \%$. The treatments that stood second and third positions were $\mathrm{Mg}-80 \mathrm{mg}$ (6.38\%) and $\mathrm{Mg}-40 \mathrm{mg}$ (6.17\%). These were followed by, K-30mg (6.16\%).

\section{Feed conversion ratio}

Feed conversion ratio of $L$. vannamei fed with dietary minerals supplementation

The Feed Conversion Ratio in different experiments of $L$. vannamei groups were calculated and presented. The range for Feed Conversion Ratio observed during the period of experiment was $0.20 \quad(\mathrm{Mg}-150 \mathrm{mg})$ 3.68(control).
During the first sampling $\left(7^{\text {th }}\right.$ day $)$ Feed Conversion Ratio ranged between 0.20 and 0.30 and the highest during this period was recorded for $\mathrm{k}-5 \mathrm{~g}, \mathrm{Na}-20 \mathrm{~g}$ and the lowest was for $\mathrm{Mg}-150 \mathrm{mg}$.

Sampling on the $14^{\text {th }}$ day shown the highest value 1.00 for $\mathrm{Na}-20 \mathrm{~g}$ and the lowest 0.82 for $\mathrm{K}-5 \mathrm{~g}$. The highest value of 1.92 was observed for $\mathrm{K}-10 \mathrm{~g}$ on $21^{\text {th }}$ day while the lower of 1.28 was recorded for Mg-150mg.

The sampling on $28^{\text {th }}$ day recorded control with highest Feed Conversion Ratio value 2.29 as same reading and lowest value of 1.73 for treatment of $\mathrm{Na}-20 \mathrm{~g}$.

The highest value of 2.41 was observed for control on $35^{\text {th }}$ day while the lowest of 2.27 was recorded for K-10g. Sampling on $42^{\text {nd }}$ day recorded highest value of 3.50 for control and lowest value of 2.47 for $\mathrm{K}-5 \mathrm{~g}$. The last sampling on $49^{\text {th }}$ day recorded control with highest Feed Conversion Ratio value 3.68 and lowest value of 2.54 for treatment of K-5g.

The Feed Conversion Ratio was subjected to analysis of variance (ANOVA) and presented. Statistical analysis has shown that F- value is found to be significant among treatments. Since F- value is found to be significant, the pair- wise comparison of any two treatments could be done by computing RBD two way classification.

The control was found to be significantly superior when compared to the other Treatments. The K-10g and Na-10g occupied second and third positions. There was a significant difference between the experimental periods also. 
Feed conversion ratio of $L$. vannamei with aqueous minerals

\section{Supplementation}

The Feed Conversion Ratio in different experiments of $L$. vannamei groups were calculated and presented.

The range for Feed Conversion Ratio observed during the period of experiment was 0.21 (K-20mg) - 3.68 (control).

During the first sampling ( $7^{\text {th }}$ day) Feed Conversion Ratio ranged between 0.21 and 0.27 and the highest during this period was recorded for control and the lowest was for K$20 \mathrm{mg}$. The $14^{\text {th }}$ day sampling shown the highest value 0.98 for $\mathrm{Mg}-40 \mathrm{mg}$ and the lowest 0.90 for K-20mg. The highest value of
1.74 was observed for $\mathrm{K}-30 \mathrm{mg}$ on $21^{\text {th }}$ day while the lowest of 1.51 was recorded for $\mathrm{Mg}$ $80 \mathrm{mg}$. The sampling on $28^{\text {th }}$ day recorded control with highest Feed Conversion Ratio value 2.29 as same reading and lowest value of 1.85 for treatment ofKa-20mg. The highest value of 2.91 was observed for K-30mg on $35^{\text {th }}$ day while the lowest of 2.41 was recorded for control. The range on $42^{\text {nd }}$ day recorded highest value of 3.50 for control and lowest value of 2.50 for $\mathrm{Mg}-80 \mathrm{mg}$. The sampling on $49^{\text {th }}$ day recorded control with highest Feed Conversion Ratio value 3.68 and lowest value of 2.88 for treatment of K-20mg.

The Feed Conversion Ratio was subjected to analysis of variance (ANOVA) and presented in table 1. Treatments found to be non significant (Plate 3 and 4).

Table.1 Proximate compositions of the various ingredients used in formulate feeds

\begin{tabular}{|l|l|l|l|l|l|l|}
\hline S.No & Ingredients & $\begin{array}{l}\text { Moisture } \\
\mathbf{\%}\end{array}$ & $\begin{array}{l}\text { Crude } \\
\text { protein } \%\end{array}$ & $\begin{array}{l}\text { Crude } \\
\text { Fat\% }\end{array}$ & $\begin{array}{l}\text { Crude } \\
\text { Fibre\% }\end{array}$ & $\begin{array}{l}\text { Ash } \\
\mathbf{\%}\end{array}$ \\
\hline 1 & Fish Meal & 8.60 & 58.10 & 10.00 & 0.30 & 19.20 \\
\hline 2 & Soya bean meal & 10.80 & 38.00 & 5.90 & 1.30 & 5.30 \\
\hline 3 & Groundnut oil cake & 6.00 & 37.70 & 13.80 & 13.20 & 7.30 \\
\hline 4 & Deoiled rice bran & 7.20 & 12.10 & 1.30 & 15.20 & 23.80 \\
\hline 5 & Maize & 15.90 & 8.00 & 4.80 & 1.10 & 1.40 \\
\hline
\end{tabular}

Plate.1 Experimental set up in the KVK

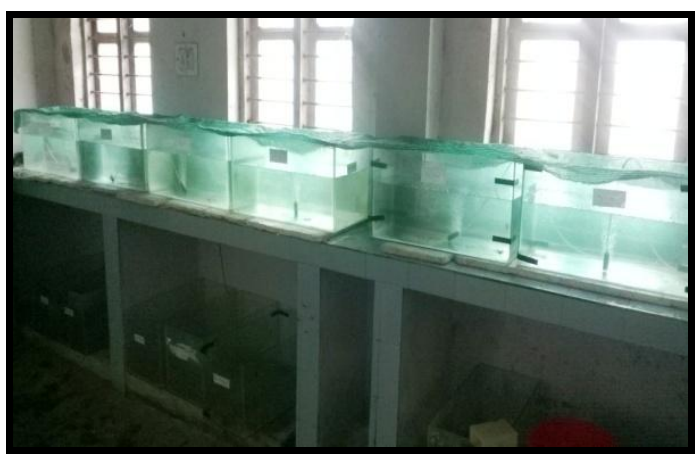

Plate.1.1 Experimental setup for dietary minerals supplementation

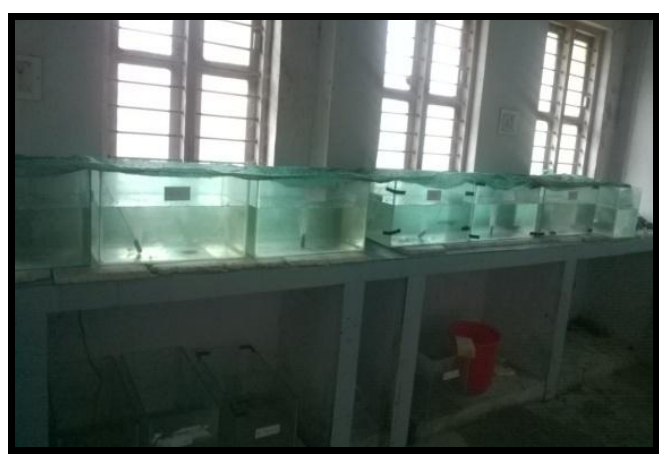

Plate.1.2 Experimental setup for aqueous minerals supplementation 


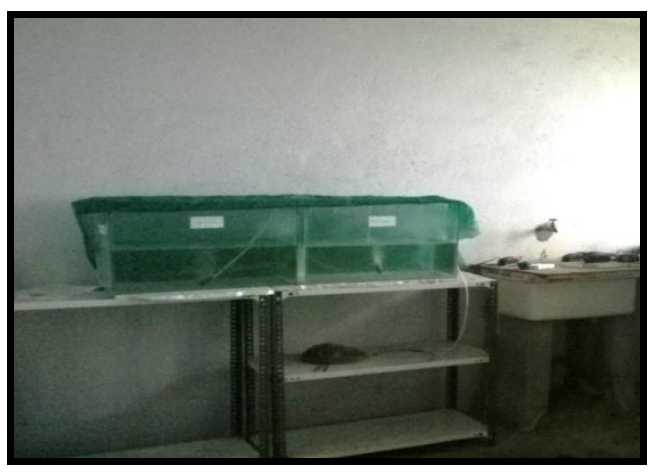

Plate.1.3 Experimental animals fed with control diet

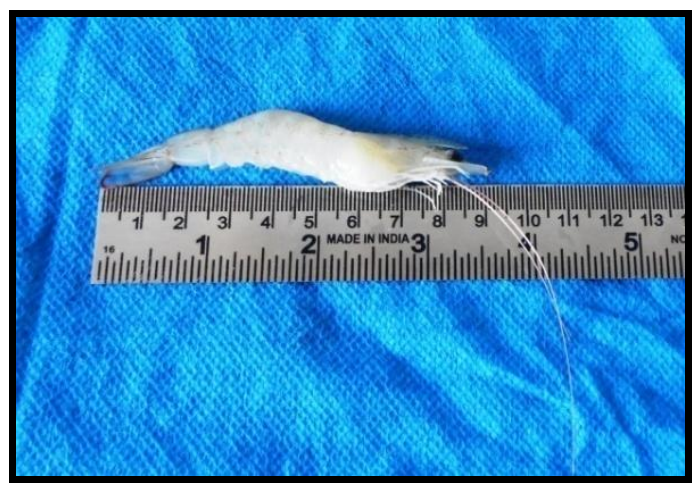

Plate.3 L. vannamei length measurement

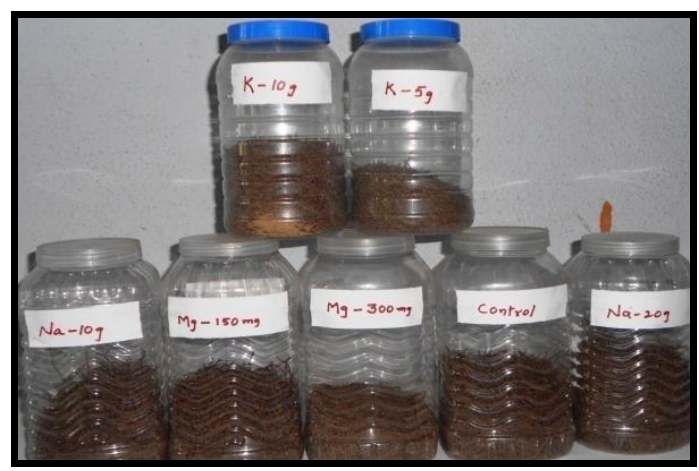

Plate.2 Practical diets used in the experiment

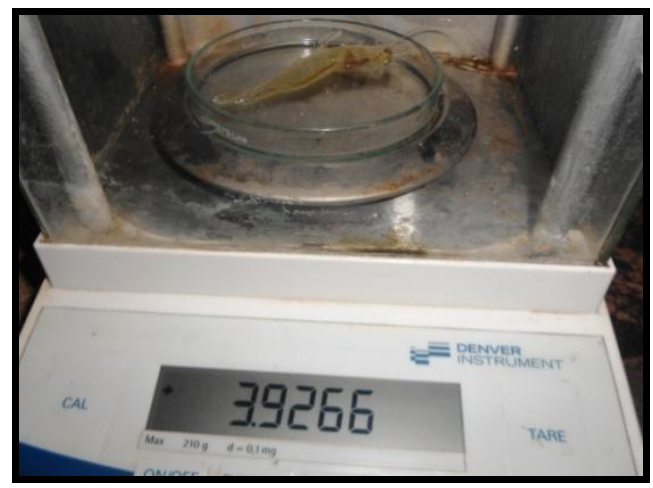

Plate.4 L. vannamei weight measurement

comparable with the salinity utilised by commercial shrimp farms where the bore wells are the basic source of water. Maintenance of sodium, potassium and magnesium is necessary for proper physiological functioning of body, osmoregulation, building of body and also as activities for many enzymes which play role in carbohydrate metabolism and protein synthesis (Davis et al., 2005).

\section{Growth of $L$. vannamei in aqueous and dietary minerals supplementation}

Dietary supplementation of $\mathrm{NaCl}$ has the potential to provide benefits for euryhaline species. In the present study growth was enhanced (3.71g) with the increase of sodium concentration $\left(\mathrm{Na}^{+} 20 \mathrm{~g} \mathrm{~kg}^{+}\right)$in the diet. In two separate studies with juvenile red drum 
(Sciaenops ocellatus) reared in freshwater, growth and feed efficiency were improved when fish were fed a diet supplemented with sodium (Holsapple, 1990; Gatlin et al., 1992). Similar feed efficiency was observed at sodium $10 \mathrm{~g}$ and $20 \mathrm{~g}$ level in the diet. The results demonstrated that, upto $10 \mathrm{~g} \mathrm{~kg}^{-1}$ supplementary sodium in experimental diet improved the specific growth rate as reported in pacific whiteleg shrimp in USA (Roy et al., 2007b). Potassium plays an important role in the membrane potential of aquatic animals. The present trail showed that there is positive correlation between potassium dietary supplementation and growth enhancement. In this trail shrimp offered with diet contain $10 \mathrm{~g}$ $\mathrm{kg}^{-1} \mathrm{~K}^{+}$yielded significantly $(\mathrm{p}<0.05)$ greater weight gain $(3.92 \mathrm{~g})$ and specific growth rate $(6.28 \%)$ than the shrimp fed with control diet.

Shiau and Hsieh (2001) were reported that increase of $\mathrm{K}^{+}$in diet increased growth in $P$. monodon. Gong et al., (2004) demonstrated the impact of $\mathrm{K}^{+}$by conducting the trail with and without mineral supplementation in $L$. vannamei. Similar trend in growth enhancement with dietary mineral supplementation was observed by many earlier works in L. vannamei (Davis et al., 2005; Muylder et al., 2006 and Roy et al., 2007b). In a field trail supplementation source of chelated $\mathrm{K}^{+}$improved growth in $L$. vannamei (Roy et al., 2007b). However, feed efficiency and feed conversion ratio(FCR)reduced with the increase of $\mathrm{K}^{+}$ supplementation from $5 \mathrm{~g} \mathrm{k}^{+} \mathrm{kg}^{-1}$ to $10 \mathrm{~g} \mathrm{k}^{+} \mathrm{kg}^{-}$ ${ }^{1}$. It may be due to higher $\mathrm{k}^{+}$supplementation levels with the increase of osmolality and respiration rates of animals and stress condition FCR reduced compared to earlier trails.

Magnesium is the major constituent of bones and skeletal parts of the animals (Davis et al., 2005). In the current study showed that significant $(p<0.05)$ increase in weight gain of
$(3.69 \mathrm{~g}) \quad$ L. vannamei with magnesium supplementation. Magnesium supplement at $300 \mathrm{mg} \mathrm{kg}^{-1}$ in practical diet showed better growth than control diet. Similar observation was made by Cheng et al., (2005) in $L$. vannamei. These authors were reported that a dietary $\mathrm{Mg}^{+2} 2.60-3.46 \mathrm{~g} \mathrm{~kg}^{-1}$ recommended for optimal growth of L. vannamei reared in low salinity water. However, Roy et al., (2007b) observed that there was no significant improvement in growth with magnesium supplementation in practical diet. On the present study higher feed efficiency, lower FCR and higher specific growth rate observed at $\mathrm{Mg}^{+2} 150 \mathrm{mg} \mathrm{kg}^{-1}$ supplementation level in the practical diet to that of control diet. Growth of the shrimp was improved when the diet were supplemented with $0.3 \%$ magnesium (Kanazawa et al., 1984). Deletion of magnesium from mineral supplemental diet results in reduced tissue mineralisation in P. vannamei (Davis et al., 1992).

Aquatic organisms collect most of their required mineral content from the surrounding water. In present study results indicated that the significant $(\mathrm{p}<0.05)$ increase in growth, lower FCR and higher specific growth rate at aqueous potassium supplementation $20 \mathrm{mg}^{-1}$ than to that of control diet. Individual weight gain and specific growth rate and percent weight gain were increased with increasing potassium concentration in aqueous source utilized in vannamei culture in low salinity waters (Roy et al., 2007a). However, in the present study weight gain, specific growth rate and feed efficiency were not increased with the increase of concentration of potassium supplementation from $20 \mathrm{mg}^{-1}$ to $30 \mathrm{mg} \mathrm{l}^{-1}$. Pragnell and Fotedar (2005) found that Penaeus latisulcatus reared in low salinity well water with $100 \%$ and $80 \%$ potassium concentration as compared to sea water resulted in slower growth. Even though potassium concentration increased weight 
gain was not observed, it may be due to at higher aqueous potassium concentration in shrimp tissue water decreases and the concentration of free amino acids in the tissue increases. With the progression of above process animal undergo stress it might have resulted in weight loss.

Addition of magnesium to the water from $40 \mathrm{mg}^{-1}$ to $80 \mathrm{mg}^{-1}$ increased growth and specific growth rate. Roy et al., (2007a) also noticed similar growth increase in $L$. vannamei low salinity culture with magnesium addition from $10 \mathrm{mg}^{-1}$ to $160 \mathrm{mg}$ $1^{-1}$. Ahmad Ali (1999) was noticed suppressed growth with the magnesium addition in diet in Penaeus indicus. He was opined that the magnesium requirement might be satisfied through absorption from the water. However, feed efficiency did not show significant difference with the magnesium addition to the water.

\section{Survival of L. vannamei in aqueous and dietary minerals supplementation}

Minerals play a significant role in the survival of pacific white shrimp in inland low salinity water culture. In the present study sodium dietary supplement trails result indicated that increase of survival $(80 \%)$ with the increase of sodium supplementation from $10 \mathrm{~g} \mathrm{~kg}^{-1}$ diet to $20 \mathrm{~g} \mathrm{~kg}^{-1}$ diet. Roy et al., (2007a) were observed that L.vennamei survival increased to $92 \%$ from $81 \%$.with an increase of sodium supplementation $20 \mathrm{~g} \mathrm{~kg}^{-1}$ diet to that of control diet. Pequeux (1995) reported that sodium and chloride ions plays significant role in osmoregulation of shrimp. These two ions were essential for the survival of shrimp in low salinity waters. In the present study shrimp offered the diet containing $10 \mathrm{~g} \mathrm{~K}^{+} \mathrm{kg}^{-}$

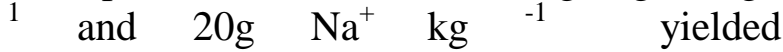
significantly $(\mathrm{p}<0.05)$ more survival than shrimp fed control diet. Our results are supported by Shiau and Hsieh (2001) in Penaeus monodon, Pragnell and Fotedar
(2005) in Penaeus latisulcatas and Roy et al., (2007b) in L. vannamei.

Survival of $L$. vannamei was increased in the diet with magnesium supplementation of $300 \mathrm{mg} \mathrm{kg}^{-1}$ to that of control diet. Roy et al., (2007b) were noticed similar increase in survival with the magnesium supplementation by using coating agents. However, Roy et al., (2007b) were observed contrasting results in the other trail without coating agent used in magnesium supplementation diet.

Ahamad Ali, (1999) reported that there was no significance affect on the survival of $P$. indicus with the supplementation of magnesium in the diet. A number of studies were documented the correlation between potassium concentration and the survival of shrimp.(Boyd et al., 2002; Davis et al., 2002; Saoud et al., 2003).

The results of the present study showed that aqueous potassium supplementation is necessary for the survival of vannamei in low salinity water culture. The shrimps have shown higher survival at the addition of potassium $30 \mathrm{mg} \mathrm{l}^{-1}$ to the water. Roy et al., (2007a) were observed similar increase in survival of vannamei with the increase of $\mathrm{K}^{+}$ in the water. Zhu et al., (2004) were observed improper $\mathrm{Na} / \mathrm{K}$ ratio in low salinity water made significant impact on survival of $L$. vannamei. Pragnell and Foteder, (2005) were reported that the potassium deficiency in low salinity water culture reduce the $P$. latisulcatus survival.

Results in the present study indicated that addition of magnesium as aqueous source to the vannamei culture in low salinity water enhanced the survival of shrimp. In the present study results showed increasing trend in survival with the increase of magnesium addition to the water. Our observation in the present experiment are also in agreement with previous studies evaluating the impact of magnesium and other minerals 
supplementation on survival of $L$. vannamei in low salinity waters (Saoud et al., 2003; Davis et al., 2005 and Roy et al., 2007a). However, Roy et al., (2007a) observed increase of survival in vannamei in low salinity water upto $40 \mathrm{mg}^{-1}$ of magnesium supplementation to the water, further addition of magnesium resulted in decrease of survival.

In conclusion it can be concluded that dietary minerals supplementation of identified minerals performed better than aqueous minerals supplementation for the enhancement of growth and survival of vannamei in low salinity water.

Further research on role of these minerals in osmoregulation of shrimp may help to answer some of the questions associated with availability in growth and sudden mortality of post larvae in vannamei culture in low salinity water.

\section{Summary}

The present experiment was conducted in the wet lab of Department of Aquaculture, College of Fishery Science, Muthukur, SPSR Nellore (District) to study the "Effect of aqueous and dietary minerals supplementation on growth and survival of L. vannamei in low salinity water". Post larvae (PL10) of $L$. vanname $i$ were brought to the wet laboratory from CP hatchery. Post larvae transported by road in plastic bags containing 15 ppt saline water. PL transferred to the same salinity water in the wet lab. Acclimatization was carried out over 8 days. During this time salinity was lowered from $15 \mathrm{ppt}$ to $3 \mathrm{ppt}$ bore well water at an average rate of $4 p p t$ day $^{-1}(\mathrm{M}$. Araneda et al., 2008). After acclimatization to 3ppt, they were transferred to experimental trail and continued mineral supplementation trails.

$>$ In the aqueous source mineral supplementation potassium was added to the water at $20 \mathrm{mg} \mathrm{l}^{-1}$ and $30 \mathrm{mg}^{-1}$. Magnesium was also evaluated as mineral through aqueous source as $40 \mathrm{mg}^{-1}$ and 80mg $1^{-1}$ concentration. Dietary supplementations of minerals were assessed with the addition of minerals sodium, potassium and magnesium at different concentration in vannamei culture in low salinity water. In control treatment shrimp fed with control diet. In case of supplementation of dietary minerals in practical diets, required mineral concentration was added to the control diet during the feed preparation. Control treatment shrimp were fed with control diet and compared the aqueous and dietary mineral supplementation for growth and survival of L. vannamei in low salinity water.

The sampling was done weekly. The duration of experiment was 7 weeks. Triplicates were maintained for all the treatments and the control. The results obtained were subjected to statistical analysis.

The results obtained in the present study on growth, survival, feed conversion ratio and specific growth rate of $L$. vannamei are summarized.

Important water quality parameters such as dissolved oxygen, temperature, $\mathrm{pH}$, total alkalinity and total hardness were analysed.

The water quality parameters were recorded in the following order, dissolved oxygen varied between $5.45-7.48$ ppm, temperature range from $29.0-30.0^{\circ} \mathrm{c}, \mathrm{pH}$ values ranged between $7.8-8.5$ and total alkalinity recorded in the range of 240$280 \mathrm{mg} \mathrm{l}^{-1}$. The water quality parameters were observed similar for all the 
treatments and control tanks throughout the experimental period.

$>$ Weekly sampling for 7 weeks was done to study growth, survival, FCR, and SGR.

$>$ In the dietary minerals supplementation treatments higher growth performance of $3.92 \mathrm{~g}$ was recorded, potassium dietary supplementation treatment $\left(\mathrm{K}^{+}-10 \mathrm{~g} \mathrm{~kg}^{-1}\right.$ diet) and lowest recorded for the control diet.

$>$ All the dietary mineral supplementation treatments were recorded higher growth than to that of control $(3.08 \mathrm{~g})$.

$>$ The analysis of variance for growth performance showed significantly difference among the treatments.

Shrimp fed on control diet had showed highest FCR, while potassium dietary supplementation $\left(\mathrm{K}^{+}-5 \mathrm{~g} \mathrm{~kg}^{-1}\right.$ diet $)$ has shown the least. All the dietary supplementation treatments showed better feed utilization efficiency than control.

> The analysis of variance for FCR has shown significant difference for all the dietary mineral supplementation treatments.

In the dietary minerals supplementation treatment highest SGR $(6.50 \%)$ was observed in magnesium dietary supplementation treatment $\left(\mathrm{Mg}^{+2}-150 \mathrm{mg}\right.$ $\mathrm{kg}^{-1}$ diet) and lowest was recorded for the control.

$>$ The highest survival of $80 \%$ and lowest of $50 \%$ recorded for shrimps fed on experimental diets with potassium dietary supplementation $\left(\mathrm{K}^{+}-10 \mathrm{~g} \mathrm{~kg}^{-1}\right.$ and

$\mathrm{Na}^{+} 20 \mathrm{~g} \mathrm{~kg}^{-1} \quad$ diet) and control respectively all the dietary mineral supplementation treatments showed better survival than the control.

In the aqueous mineral supplementation treatments highest growth performance $3.65 \mathrm{~g}$ was recorded for magnesium treatment $\left(\mathrm{Mg}^{+2}-80 \mathrm{mg} \mathrm{l}^{-1}\right)$ addition to the water and lowest in control.

All the aqueous mineral supplementation treatments showed better growth performance than to that of control.

Analysis of variance for growth performance showed significant difference among the treatments.

FCR observed highest in the potassium addition to the water $\left(\mathrm{K}^{+}-20 \mathrm{mg} \mathrm{l}^{-1}\right)$ in aqueous mineral supplementation treatments and lowest recorded in control.

In the aqueous mineral supplementation treatments highest SGR (6.50\%) was observed in potassium supplementation $\left(\mathrm{K}^{+}-20 \mathrm{mg}^{-1}\right)$ and lowest recorded for the control.

The highest survival of $70 \%$ and lowest of $50 \%$ was recorded in potassium $\left(\mathrm{K}^{+}\right.$$30 \mathrm{mg} \mathrm{l}^{-1}$ ) addition to the water treatment and control respectively. All the aqueous mineral supplementation treatments demonstrated better survival than the control.

Analysis variance for the survival showed significant difference among all treatments.

It can be concluded that dietary mineral supplementation of minerals performed better than aqueous mineral supplementation for the enhancement of growth and survival of vannamei in low salinity water culture. 
$>$ Potassium inclusion at $\left(\mathrm{K}^{+}-10 \mathrm{~g} \mathrm{~kg}^{-1}\right.$ diet $)$ is identified as optimal level of inclusion for vannamei culture in low salinity water.

\section{References}

Ahmad Ali, S. (1999). Calcium, Phosphorus and Magnesium Requirements in the Diet of shrimp Penaeus indicus. Asian Fisheries Science 12(1999):145-153

Alday-Sanz, V. (2010). The Shrimp Book: Theory and Practice of Penaeid Aquaculture. Nottingham University Press, Nottingham.

AOAC. (1995). Official Methods of Analysis of the Association of Official Analytical Chemists. Washington, Dc. pp.101.

APHA (American Public Health Association). (1995). Standard methods for the examination of water and waste water, $19^{\text {th }}$ ed. American Public Health Association, Washington, DC.

Araneda, M., Perez, E.P., Gasca-Leyva, E. (2008). White shrimp Penaeus vannamei culture in freshwater at three densities: condition state based on length and weight. Aquaculture 283: 13-18.

Atwood, H.L., Young, S.P., Tomasso, J.R., Browdy, C.L. (2003). Survival and growth of Pacific white shrimp Litopenaeus vannamei postlarvae in low-salinity and mixed-salt environments. J. World Aquac. Soc. 34, 518-523.

Boyd, C.E., Thunjai, T., Boonyaratpalin, M. (2002). Dissolved salts in water for inland, low-salinity shrimp culture. Global Aquaculture Advocate. 5(3). Pp. $40-45$.

Boyd, C.E. and Thunjai, T. (2003). Concentrations of major ions in waters of inland shrimp farms in China, Ecuador, Thailand, and the United States. Journal of the World
Aquaculture Society 34, 524-532

Boyd, C.E. (2003). Comparison of ionic composition of water from pond for inland culture of marine shrimp in the United States. CD of abstracts $\mathrm{N}^{\circ} 30$. World Aquaculture Society 2003, May 21-24. Bahía. Brasil.

Bray, W.A., Lawrence, A.L., Leung-Trujillo, J.R. (1994). The effect of salinity on growth and survival of Penaeus vannamei, with observations on the interaction of IHHN virus and salinity. Aquaculture 122: 133-146.

Cheng, K.M., Hu, C.Q., Liu, Y.N., Zheng, S.X. and Qi, X.J. (2005). Dietary magnesium requirement and physiological responses of marine shrimp Litopenaeus vannamei reared in low salinity water. Aquaculture Nutrition 11, 385-393.

Cuvin-Aralar, M.L.A., Lazartigue, A.G., Aralar, E.V. (2009). Cage culture of the Pacific white shrimp Litopenaeus vannamei (Boone, 1931) at different stocking densities in a shallow eutrophic lake. Aquaculture Research 40: 181-187.

Dall, W., Hill, B.J., Rothlisberg, P.C., Staples, D.J. (1990). The biology of Penaeidae. Advances in Marine Biology 27. Academic Press, London.

Davis, D.A., Lawrence, A.L. and Gatlin, D.M., III. (1992). Mineral requirements of Penaeus vannamei: a preliminary examination of the dietary essentiality for thirteen minerals. $J$. World Aquacult. Soc. 23, 8-14.

Davis, D.A., Lawrence, A.L. (1993). Responce of Penaeus vannamei to dietary calcium, phosphorus and calcium: phosphorus ratio. Journal of World aquaculture Society 24(4): 504515.

Davis, D.A., Saoud, I.P., McGraw, W.J., Rouse, D.B. (2002). Considerations for Litopenaeus vannamei reared in 
inland low salinity waters. In: CruzSua'rez IE, Ricque-Marie D, TapiaSalazar M, Gaxiola-Corte's MG, Simoes N (eds) Avances en Nutricio 'n Acuicola VI, pp. 73-90. Memorias del VI Simposium Internacional de Nutrición Acuicola, Cancu' n.

Davis, D. A., Saoud, I.P. and Rouse, D.B. (2003a). Effects of potassium, magnesium and age on acclimation of Litopenaeus vannamei postlarvae to inland saline well-waters in west Alabama. CD of abstracts $\mathrm{N}^{\circ} 254$. World Aquaculture Society 2003, May 21-24. Bahía. Brasil.

Davis, D.A., Saoud, I.P., Boyd, C.E., Rouse, D.B. (2005). Effects of potassium, magnesium, and age on growth and survival of Litopenaeus vannamei post-larvae reared in inland low salinity well waters in west Alabama. Journal of the World Aquaculture Society 36: 403-406.

Deshmaru, O. and Yone, Y. (1978). Requirment of prawn for dietary minerals. Bulleten of the Japanese Society of Scientific Fisheries 44(8): $907-910$.

FAO (Food and Agriculture Organization of the United Nations) (2011). The State of World Fisheries and Aquaculture 2008. FAO Fisheries and Aquaculture Department. Food and Agriculture Organization of the United Nations, Rome.

Flaherty, M., Vandergeest, P. (1998). "Lowsalt" shrimp aquaculture in Thailand: Goodbye coastline, hello Khon Kaen. Environmental Management. 22(6): 817-830

Gatlin, D.M. III., MacKenzie D.S., Craig, S.R. and Neil, W.H. (1992). Effects of dietary sodium chloride on red drum juveniles in waters of various salinities. Progressive Fish Culturist 54, 220-227.
Gilles, R. and Piquex, A. (1983). Interaction of chemical and osmoregulation with the environment. In: D.E Bliss (Chief ed.), Biology of crustacea Vol. 8. Environmental Addoption. Acadamic Press: $109-177$.

Gong, H., Jiang, D.H., Lightner, D.V., Collins, C. and Brock, D. (2004). A dietary modification approach to improve the osmoregulatory capacity of Litopenaeus vannamei cultured in the Arizona desert. Aquacult. Nutr. 10, 227-236.

Holsapple, D.R. (1990). The effects of dietary sodium chloride on red drum (Sciaenops ocellatus) in fresh and brackish water. Master's Thesis, Texas A\&M University, College Station.

Hysmith, B.T., J.R. Booth, H.L. Cook and W.L. Mies. (1972). Astudy of the effect of feeding synthatic diets to brown shrimp (Penaeus aztucus). Proceedings of the World Mariculture Society 3: $365-388$.

Jameson, J.D., Srinivasan, A and Venkataramanujam, K. (1995). Ornamental fish culture technology. TANUVAS publication. No. BMO1/95. Chennai, p.103.

Kahoun, F. and B. Baca. (2003). Acclimation of Pacific white shrimp Litopenaeus vannamei to low salinity waters of south Florida. CD of abstracts $\mathrm{N}^{\circ} 137$. World Aquaculture Society 2003, May 21-24. Bahía. Brasil.

Kanazawa, A. (1985a). Microparticulate diets for prawn larve. Yoshuku 22(2): 44 47 (in Japanese).

Lee, P.G., Zuercher, C., Davies, C., Lawrence, A.L., Samocha,T., Woods, G., and Turk, P.E. (2001). Biosecure, commercial, inland marine shrimp raceway production and environmentally isolated, SPF broodstock culture systems. Book of 
abstracts. Aquaculture 2001, January 21-25. World Aquaculture Society. Florida. USA. Pp. 363.

Lovell, T. (1989). Nutrion and Feeding of Fish. New York: Van Nostrand Reinhold (1989)

Martinez C., L. (1999). Cultivo de camarones peneidos. Principios y prácticas. $1^{\circ}$ edición. Editorial A.G.T. Editor S.A. México D.F. México. Pp. 123-124

McGraw, J.W., Davis, D.A., TeichertCoddington, D., Rouse, D.B. (2002). Acclimation of Litopenaeus vannamei postlarvae to low salinity: influence of age, salinity endpoint, and rate of salinityreduction. J. World Aquac. Soc. 33, 78-84

McGraw, J.W. and Scarpa, J. (2004). Mortality of freshwater-acclimated Litopenaeus vannamei associated with acclimation rate, habituation period, and ionic challenge. Aquaculture 236, 285-296.

McNevin, A.A., Boyd, C.E., Silapajarn, O., Silapajarn, K. (2004). Ionic supplementation of pond waters for inland culture of marine shrimp. Journal of the World Aquaculture Society 35: 460-467.

Muylder, E.D., Huynh Thi Tu and Marijke Van Speybroek (2006). The influence of Macro-Minerals $\left(\mathrm{Ca}^{++}, \mathrm{PO}_{4}^{-}, \mathrm{Mg}^{++}\right.$ and $\mathrm{K}^{+}$) in the diet on growth of Litopenaeus vannamei at low salinities. Aqua Feeds: Formulation \& beyond, Volume 2, Issue 32006.

National Research Council (1993). Nutrient Requirements of Fish. Washington, D.C.: Natonal Academy Press (1993).

Pequeux, A. (1995). Osmotic regulation in crustaceans. Journal of Crustacean Biology 15: 1-60.

Prangnell, D.I. and Fotedar, R. (2005). The effect of potassium concentration in inland saline water on the growth, survival of the western king shrimp,
Penaeus latisulcatus Kishinouye, 1896. Journal of Applied Aquaculture 17(2): 19-33.

Rothlisberg, P.C. (1998). Aspects of penaeid biology and ecology of relevance to aquaculture: a review. Aquaculture 164: 49- 65.

Roy, L.A., Davis, D.A., Saoud, I.P., Henry, R.P. (2007a). Effects of varying levels of aqueous potassium and magnesium on survival, growth, and respiration of the Pacific white shrimp, Litopenaeus vannamei, reared in low salinity waters. Aquaculture 262: 461-469.

Roy L.A., Davis D.A., Saoud I.P. and Henry R.P. (2007b). Effects of varying levels of aqueous potassium and magnesium on survival, growth, and respiration of the Pacific white shrimp, Litopenaeus vannamei, reared in low salinity waters. Aquaculture 262, 461-469.

Roy, L.A., Davis, D.A., Whitis. G.N. (2009a) Pond-to-pond variability in post-larval shrimp, Litopenaeus vannamei, survival and growth in inland low salinity waters of west Alabama. Aquaculture Research 40: 1823-1829.

Samocha, T.M., Hamper, L., Emberson, C.R., Davis, D.A., McIntosh, D., Lawrence, A.L., Van Wyk, P. (2002). Review of some recent developments in sustainable shrimp farming practices in Texas, Arizona, and Florida. $J$. Appl. Aquac. 12, 1-30.

Samocha, T.M., Lawrence, A.L., Pooser, D. (1998). Growth and survival of juvenile Penaeus vannamei in low salinity water in a semi-closed recirculating system. Israeli Journal of Aquaculture 50: 55-59.

Sanchez-Barajas, M., Liñan-Cabello, M. A., Mena-Herrera, A. 2009. Detection of yellow-head disease in intensive fresh water production systems of Lithopenaeus vannamei. Aquaculture International. 17:101-112 
Saoud I.P., Davis D.A. and Rouse D.B. (2003). Suitability studies of inland well waters for Litopenaeus vannamei culture. Aquaculture 217, 373-383.

Schmidt-Nielsen, K. (1984). Fisiología animal. adaptación y medio ambiente. Primera reimpresión. Ediciones Omega S.A. Barcelona. España. Pp. $263-310$.

Scott, M.L., Nesheim, M.C., Young, R.J. (1982). Nutrion of the chicken. New York:M.L.Scott and Associates (1982).

Shiau, S.Y. and Hsieh, J.F. (2001). Dietary potassium requirement of juvenile grass shrimp. Penaeus monodon. Fish. Sci. 67, 592-595.

Sick, L.V., Andrews, J.D. and White, D.B. (1972). Preliminary studies on selected environment and nutritional requirments for the culture of penaeid shrimp. Fishereis Bulletin 70: 101 109.

Sowers, A.D., Browdy, C.L., Atwood, H.L., Tomasso, J.R. (2006a). Production characteristics of Litopenaeus vannamei in low salinity water augmented with mixed salts. Journal of the World Aquaculture Society 37: 214-217.

Van Wyk, P., Davis-Hodgkins, M., Laramore, C.R., Main, K.L., Mountain, J., Scarpa, J. (1999). Farming marine shrimp in recirculating freshwater systems. FDACS contract M520. Florida Department of Agriculture and Consumer Services, Tallahassee, Florida, USA.

Vijayan, K. and A.D. Diwan. (1996). Fluctuations in $\mathrm{Ca}, \mathrm{Mg}$ and $\mathrm{P}$ levels in the hemolymph, muscle, midgut gland and exoskeleton during moulting cycle of the Indian white prawn, Penaeus indicus (Decapoda: Penaeidae) Comparetive biochemistry and physiology 114A (I): 91 - 97.

Wilson, J. A. (1989). Fundamentos de fisiología animal. Primera edición. Editorial Limusa. México D.F. México. Pp. 42.

Zhu, C., Dong, S., Wang, F., Huang, G. (2004). Effects of $\mathrm{Na} K$ ratio in seawater on growth and energy budget of juvenile Litopenaeus vannamei. Aquaculture 234: 485-496.

\section{How to cite this article:}

Veeranjaneyulu, K. and Krishnaveni, G. 2018. Role of Minerals Supplementation on Growth and Survival of Litopenaeus vannamei in Low Salinity Water. Int.J.Curr.Microbiol.App.Sci. 7(12): 3041-3058. doi: https://doi.org/10.20546/ijcmas.2018.712.349 